\title{
Productivity Growth and Entrepreneurship in Pakistan: The Role of Public Policy in Promoting Technology Management
}

\section{Shaukat Hameed Khan *}

\begin{abstract}
Numerous public announcements are made regularly in Pakistan about moving towards a knowledge economy. These appear to be wishful thinking in the absence of any coherent understanding of the role of technology and its spillovers as major drivers of development and growth as well as lack of clarity about the manner in which science and technology are organized in Pakistan. Pakistan has not really been able to manage the major organizational changes brought about by the technoinformation revolution of the 21st century. Its competitiveness is falling, organizational changes are slow and workforce skill levels are inadequate - all of which have stalled productivity and innovation. Pakistan faces a serious risk of deindustrialization unless the dynamics and disruptive nature of modern technology are better understood and embedded as a key pillar of public policy in order to enhance productivity and innovation. This article attempts to define the nexus between technology and entrepreneurship and show how it differs from scientific research. It also examines the role of public policy in promoting productivity growth and entrepreneurship through better policies in technology management.
\end{abstract}

Keywords: Productivity, growth, entrepreneurship, public policy, technology, Pakistan.

JEL classification: O39.

\section{Introduction}

Economic advancement is an extremely complex process. Science and technology (S\&T) alone is not a magic wand. Lessons from numerous growth studies show that it is not possible for a country to replicate exactly those that have gone before; latecomers must dance to their own music. This, however, needs some good orchestration.

\footnotetext{
* Coordinator general, COMSTECH (OIC Standing Committee on Scientific and Technological Cooperation). Former member, Planning Commission. Rector, Ghulam Ishaq Khan Institute of Engineering Sciences and Technology.
} 
In order to identify public policies that promote better management and acquisition of technology in Pakistan, it is necessary first to understand the emerging morphology of the global economy. Its distinctive feature is the transnational/vertical division of labor and diffusion of work, technology and ownership, which requires matching transnational skills. From the 1970s to the 1990s, it was shown that manufacturing could be done anywhere. Now, designing, too, can be undertaken anywhere and this shift appears to be irrevocable. Other intrinsic factors remain the development of institutional excellence and fast-moving human resources, coupled with strategic alliances for complementary resources. The key drivers of growth are, and will remain, people, innovation and capital. These, however, require a strong congruence between social and technological capabilities.

Almost all developed economies are now identified as 'knowledge economies' to some extent or the other and they are taking further steps to consolidate this position by becoming even more knowledge-intensive and competitive (Romer, 1994). Even when their productivity growth has slowed down, the rate of increase in the skill bias in technology has not. In some newly industrialized Asian countries, such activities have already enabled small and medium enterprises (SMEs) to evolve into major global players and conglomerates, which now offer complete end-to-end services in the supply chain, whether as manufacturers of piece parts and systems or providers of services, design and research. Developing countries, too, have witnessed a sharp reduction in the relative demand for unskilled labor since the end of the 1970s.

\subsection{Playing Catch $U p$}

Historically, there have been several major attempts at playing 'catch up' during the last 150 years and the dynamics of the process have been studied extensively. These include German attempts to emulate the earlier industrial revolution in Britain (Gerschenkron, 1962) and the forced modernization of Meiji Japanese society (Morishima, 1982), both of which took place in the 19th century. More recent studies have focused on the postwar boom in Europe, the sudden rise of newly industrialized countries in East Asia and, of course, China.

The basic lesson from growth studies is that it is not possible to replicate the policies of countries that took the route earlier because of that moment in history, such as empires, captive economies, colonies and division of labor. Today, it is about the digital disruption, automation and the death of distance brought about by the information revolution, with 
totally different dynamics for adoption. Further, while economic integration, larger and more homogeneous markets and large-scale production technologies have driven growth and development, the process of sustained growth experienced by several countries and regions would not have been possible without a general increase in education levels and human capital (Barro \& Lee, 2000).

Recently, the emergence of a congruence has been observed in the modern sectors of the economy, which show a "robust tendency toward convergence in labor productivity in such manufacturing activities ... regardless of geography, policies or other country-level influences" (Rodrik, 2013). This is caused by extremely rapid changes in the technology innovation cycle and its absorption by countries that are ready for this disruption. The basic requirement, however, remains the congruence of technological and social capabilities and infrastructure (Abramovitz, 1994), which in turn require the institutional evolution of domestic knowledge systems.

Innovation activities in firms are ascribed as the driving force behind economic growth, brought about by new combinations of science and engineering, market research and organizational experience, all of which promote more qualitative than quantitative activities (the "creative destruction" proposed by Schumpeter in 1976). Lundvall (1992, 2005), meanwhile, emphasizes learning as the source of technological growth (learning by doing) while Romer (1994) focuses on innovation and research and development (R\&D) with its externalities and spillovers to improve the capacity for future innovation.

\subsection{Technology Management and Entrepreneurship}

While there is a considerable body of literature available in economics and development or in entrepreneurship and management, the field of technology entrepreneurship is still in its infancy and detailed studies are few and far between. The result is that entrepreneurship, especially technology entrepreneurship, can be as difficult to teach as public morality (Socrates having asked, "Can morality be taught?"). Moreover, most literature on technology management relates to large enterprises that have dedicated resources for managing assets and achieving productivity gains. Technology management operations in SMEs are generally very patchy and informal. 
Bailetti (2012) examines all articles published in 62 major journals between 1970 and 2011 across eight related themes and notices a rapid increase in the volume and breadth of research on technology entrepreneurship. Two thirds of the articles were published in the last 12 years, of which 84 percent deal with four topics only. The majority (45 percent) examine the external factors that influence the formation of technology firms; 15 percent discuss how, why and when technology entrepreneurship affects the socioeconomic development of a region; 13 percent cover the approaches used by small technology firms to generate revenues, reduce costs, manage operations and business transformation; and 11 percent deal with the internal practices used to operate and transform small technology firms. Since 1970, a mere four articles, or 4 percent of all the articles, have dealt with an overview of technology entrepreneurship, of which two were published in 2000-09 and one in 2011.

\subsection{Science, Technology and Productivity}

A recent report by Manyika et al. (2013) identifies 12 technology areas with a potentially huge impact on how people live and work and how industries and economies will evolve by 2025 , based on extensive interaction with experts and respected leaders in industry and academia. While such changes have always been disruptive, the speed of change and their scope have accelerated. Their potential impact needs to be carefully examined and leveraged in state policies. The report also points out that, unlike previous innovations, "the benefits of technological change are not being widely shared - real median wages have fallen behind growth in productivity and inequality has increased."

A further disruption is caused by the blurring of boundaries between scientific research and technology application, especially in the realms of molecular biology and computers and information ('big data' and IT). The two communities of researchers and technologists and their activities do not differ as much in their methods of enquiry and pursuit of knowledge as in their reward structures and approach to the disclosure of knowledge (Dasgupta \& David, 1994). The fundamental difference between the two strains is the division between public and private knowledge systems, science being supposedly free - the philosophy of the 'Republic of Science' (Polanyi, 1962) - while technology is driven by secrecy, profits and the production of industrial goods and services or military hardware.

Moreover, the knowledge worker does not necessarily hold a $\mathrm{PhD}$. For productivity gains, the skilled worker may be more important than the 
research scientist and covers the entire spectrum of new skills required, whether it is the telephone operator or the fisherman and farmer, the worker on a building site or the people who maintain and operate essential infrastructure.

\section{The State of Productivity and Competitiveness in Pakistan}

Pakistan's overall competitiveness is quite low and its ranking on the global competitiveness index (GCI) fell from 83 in 2007 to 126 in 2016 (Figures 1-3). The Global Competitiveness Report for 2015/16 (prepared by the World Economic Forum for 144 countries) identifies 12 'pillars' that contribute to productivity and competitiveness. Four of these are directly linked to skills: primary education, higher education and training, business sophistication and innovation. The indirect pillars include technological readiness (which measures how a country implements existing technologies to improve productivity) in addition to labor market efficiency. The primary cause of Pakistan's poor performance is poor performance against the basic requirements (see Figure 3), which carry a weight of 60 percent in the evaluation.

Figure 1: Pakistan's competitiveness ranking, 2007-16

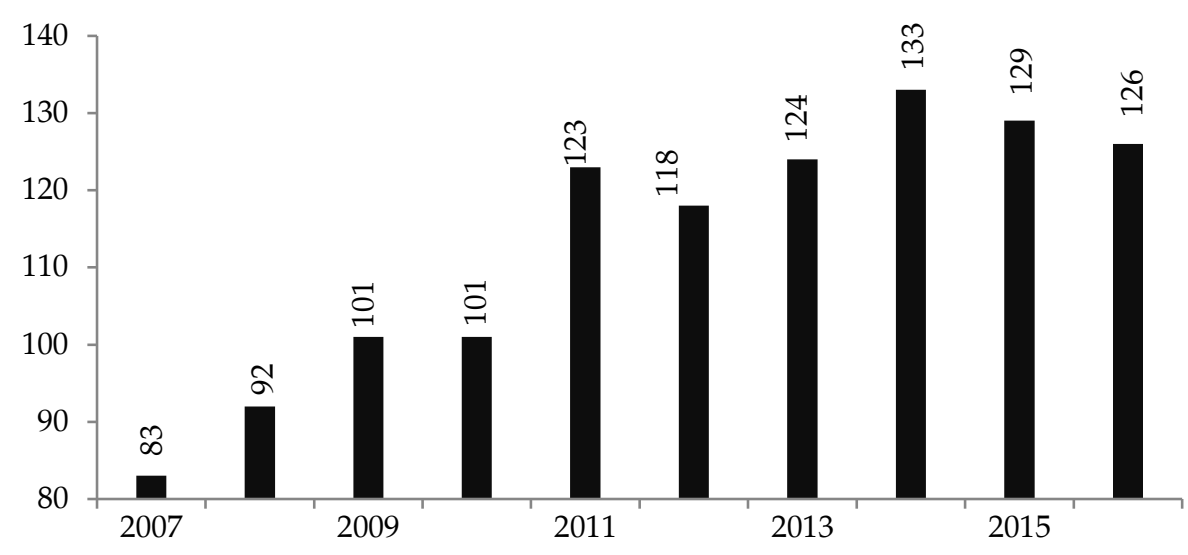

Source: World Economic Forum (2016). 
Figure 2: Overall GCI ranking out of 140 countries

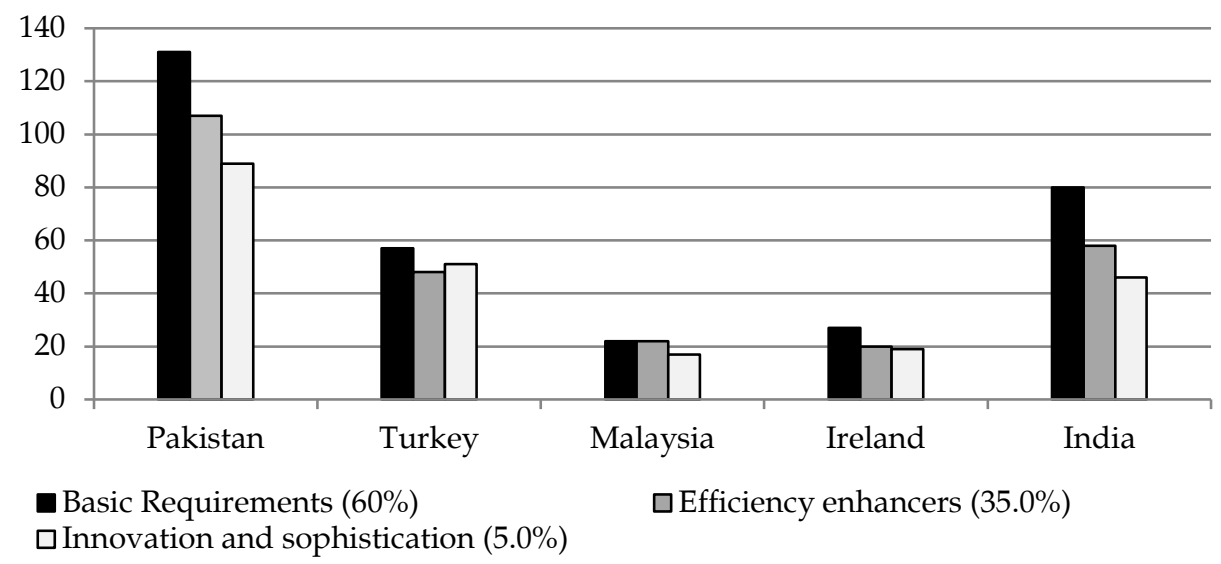

Source: World Economic Forum (2016).

\section{Figure 3: GCI ranking, basic requirements}

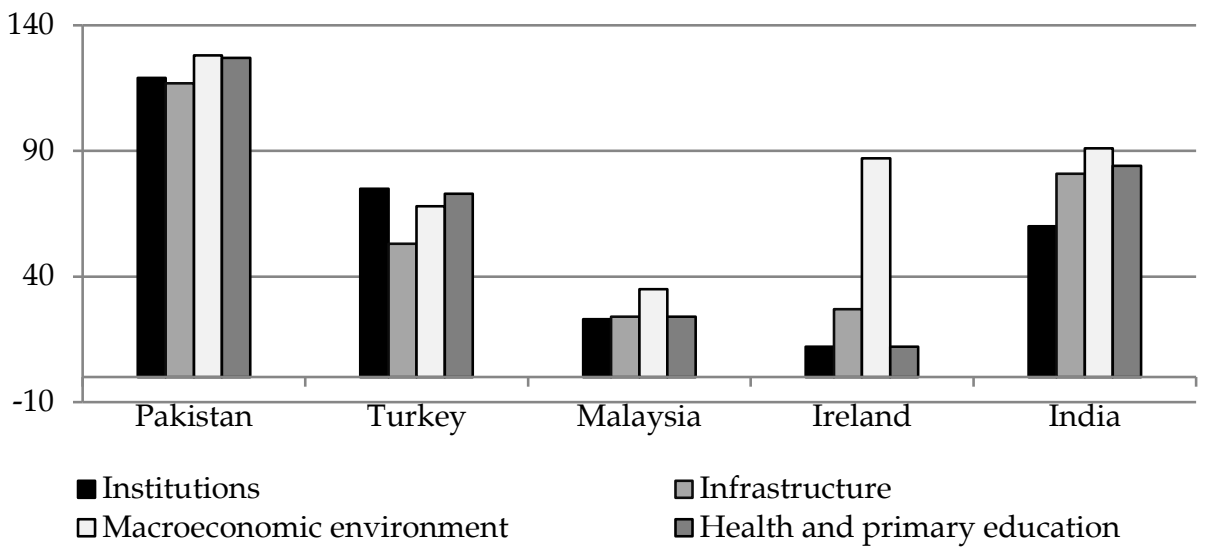

Source: World Economic Forum (2016).

When it comes to technological readiness or the capacity for innovation (Table 1), Pakistan fares badly overall, being ranked the lowest among the five selected countries in nine out of seven sub-indicators. Surprisingly, Pakistan fares better than India in the availability of the latest technology and firm-level technology absorption as well as foreign direct investment (FDI) and technology transfer. ${ }^{1}$ This is surprising, given its much lower ranking in the basic requirements group (see Figure 3). Ireland leads in FDI and technology transfer, followed by Malaysia and Turkey.

\footnotetext{
${ }^{1} \mathrm{R} \& \mathrm{D}$ readiness is discussed extensively by Berteletti, Morel and Teulieres (2016).
} 
An important indicator of productivity and innovation within the global economic environment is the share of manufacturing in GDP and exports. The ratio of Pakistan's exports to GDP is quite small (12.5 percent). The worrying feature is that its biggest components are cotton and agricultural products. Exports of high-technology goods and services - such as computers and office machinery, communications semiconductors, aerospace, pharmaceuticals and scientific and measuring equipment - have a low share (Pakistan Bureau of Statistics, 2015; World Bank, 2015). This is shown for five selected countries in Figure 4.

\section{Table 1: Technological readiness and innovation in selected countries}

\begin{tabular}{|c|c|c|c|c|c|}
\hline 9th pillar: technological readiness & Pakistan & Turkey & Malaysia & Ireland & India \\
\hline Availability of latest technology & 79 & 55 & 30 & 17 & 108 \\
\hline Firm-level technology absorption & 82 & 36 & 23 & 24 & 102 \\
\hline FDI and technology transfer & 77 & 52 & 5 & 1 & 95 \\
\hline Individuals using the Internet, $\%$ & 119 & 67 & 45 & 28 & 117 \\
\hline Fixed BB Internet subscribers, \% & 107 & 61 & 68 & 29 & 104 \\
\hline $\begin{array}{l}\text { Int. Internet bandwidth, } \mathrm{kb} / \mathrm{s} \text { per } \\
\text { user }\end{array}$ & 115 & 62 & 77 & 16 & 116 \\
\hline \multicolumn{6}{|l|}{ 12th pillar: innovation } \\
\hline Capacity for innovation & 95 & 83 & 7 & 17 & 50 \\
\hline $\begin{array}{l}\text { Quality of scientific research } \\
\text { institutions }\end{array}$ & 104 & 82 & 20 & 15 & 45 \\
\hline Company R\&D & 88 & 79 & 8 & 19 & 31 \\
\hline $\begin{array}{l}\text { University/industry R\&D } \\
\text { collaboration }\end{array}$ & 98 & 61 & 12 & 13 & 50 \\
\hline $\begin{array}{l}\text { Government procurement } \\
\text { (advanced technological products) }\end{array}$ & 52 & 39 & 3 & 51 & 26 \\
\hline $\begin{array}{l}\text { Availability of scientists and } \\
\text { engineers }\end{array}$ & 44 & 50 & 5 & 8 & 49 \\
\hline Patents application/million & 109 & 42 & 33 & 20 & 61 \\
\hline$=$ worst $\quad=$ best & & & & & \\
\hline
\end{tabular}


Figure 4: Manufacturing and export profiles for selected countries, 2015

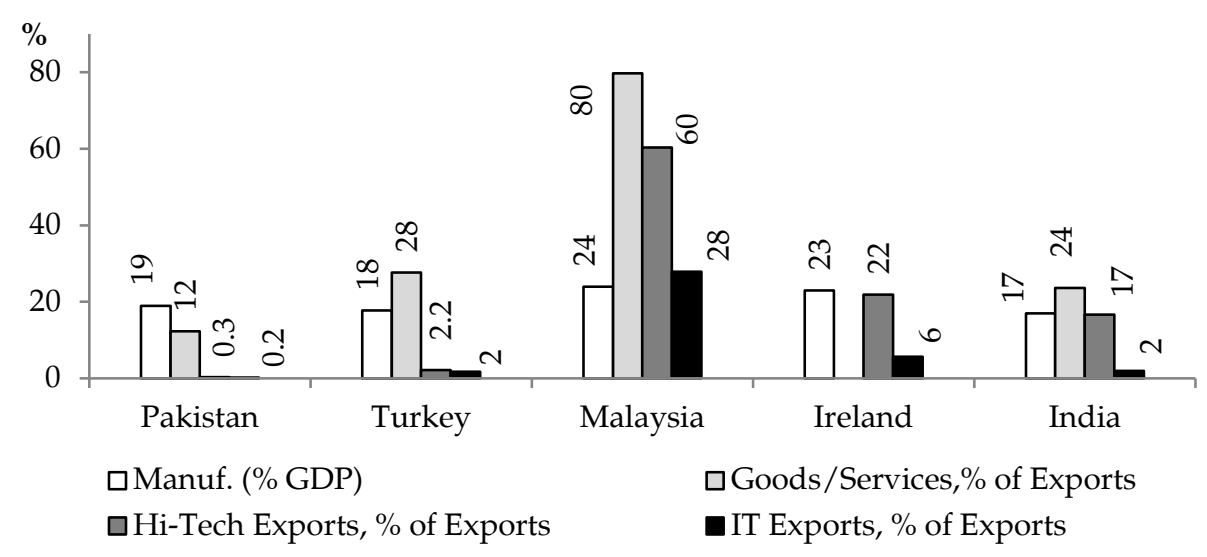

Cotton and its derivatives, or the goods produced by the Sialkot export group, have low growth rates and demand, while technology-based items, especially electronics, have larger global turnovers and growth. These sectors are also highly competitive. China and East Asia are growing the fastest in the high-technology merchandise exports category, but the US and EU are still the biggest providers of knowledge-intensive services (Figure 5).

Figure 5: High-technology exports and commercial knowledgeintensive services as \% of global exports, 2014
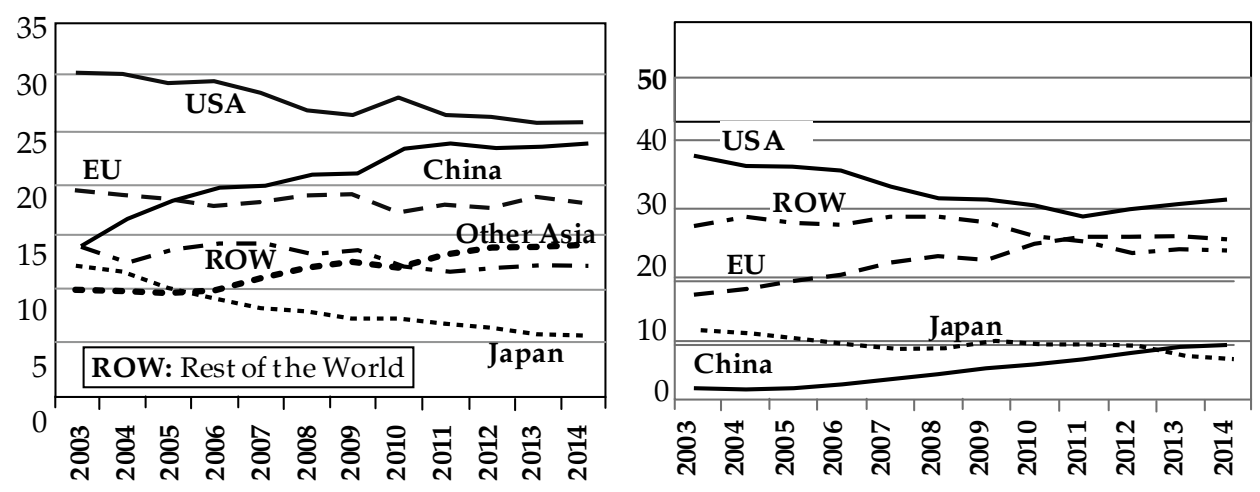

\section{Patents as a Proxy for Innovation, FDI and Terms of Trade}

Patent applications are an important proxy for industrialization, entrepreneurship and research. The share of OIC member states in the 2.7 million global patent applications filed in 2014 was only about 50,000 or 1.9 percent (World Intellectual Property Organization, 2015). The share of 
'residents' in patent applications was also very small, except for Turkey and Iran, indicating weaknesses in local systems. In comparison, just five countries accounted for 89 percent of global patent applications, with China leading with 965,000 (36 percent), followed by the US $(803,000$ or 30 percent), South Korea (277,000 or 10 percent), Germany $(197,000$ or 7 percent), India (147,000 or 5 percent) and France ( 74,000 or 3 percent). These numbers reflect the state of investment and activities in the modern sectors of their economies.

Pakistan fares badly even among the OIC countries (Figure 6), with just 978 applications or about 2 percent of the total number filed by OIC countries in 2014 (World Intellectual Property Organization, 2015). Of these, 146 were filed by residents, 776 by nonresidents and 56 filed abroad. Globally, Pakistan's share was a negligible 0.04 percent, which reflects not only its low innovative capability, but also lack of investment and intellectual property protection. It also implies the absence of the diffusion of innovations and best practices from leading global firms, especially 'frontier firms', which have higher productivity levels than nonfrontier or large firms (OECD, 2015).

\section{Figure 6: Patent applications, top nine OIC countries}

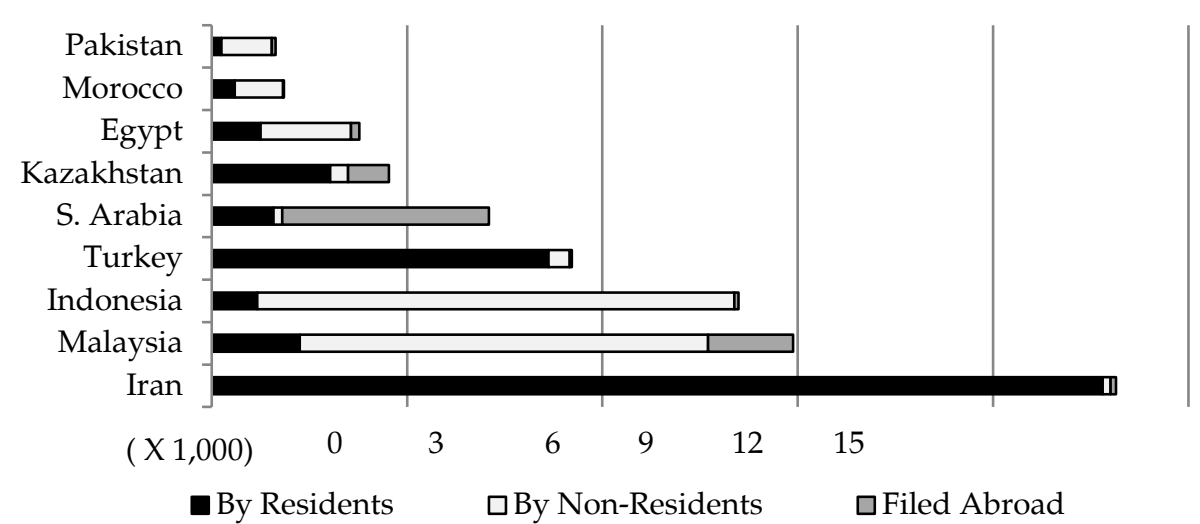

Source: World Intellectual Property Organization (2015).

The categories in which patents are created in Pakistan are given in Figure 7, with computers and digital communication, telecoms and pharmaceuticals being the top four categories. 
Figure 7: Pakistani patents, by field

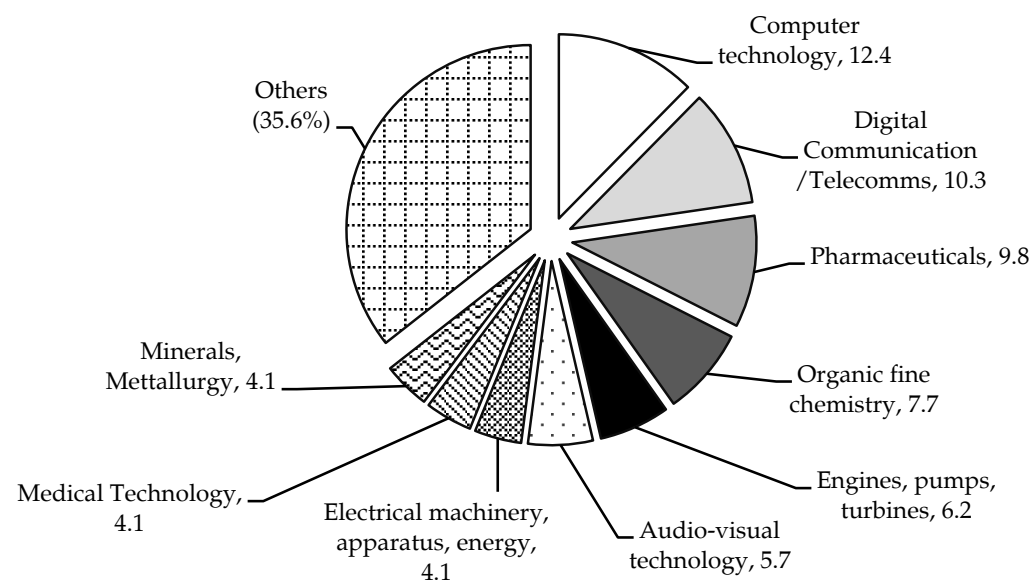

Source: World Intellectual Property Organization (2015).

Incidentally, the IT and software sector is not adequately reflected in patents or exports because of innumerable 'virtual' services and transactions

\section{The Causes of Low Productivity in Pakistan}

This section looks at the relationship between productivity and education.

\subsection{The Education Crisis}

Low productivity in Pakistan can be attributed to one key factor: the crisis in its education system. Of the 30.6 million children enrolled in school in 2014, the share of secondary schooling is 3.6 million (11.7 percent) while that of technical and vocational education is only 0.32 million (1.04 percent). This reflects a major problem in education as regards to completion and skills development. The Pakistan Labor Force Survey for 2009 gives even more startling numbers for education levels among the workforce: nearly three quarters had less than eight years of schooling and a third had attended school for only one year (see Figure 8). 
Figure 8: Education profile of Pakistan, 2016

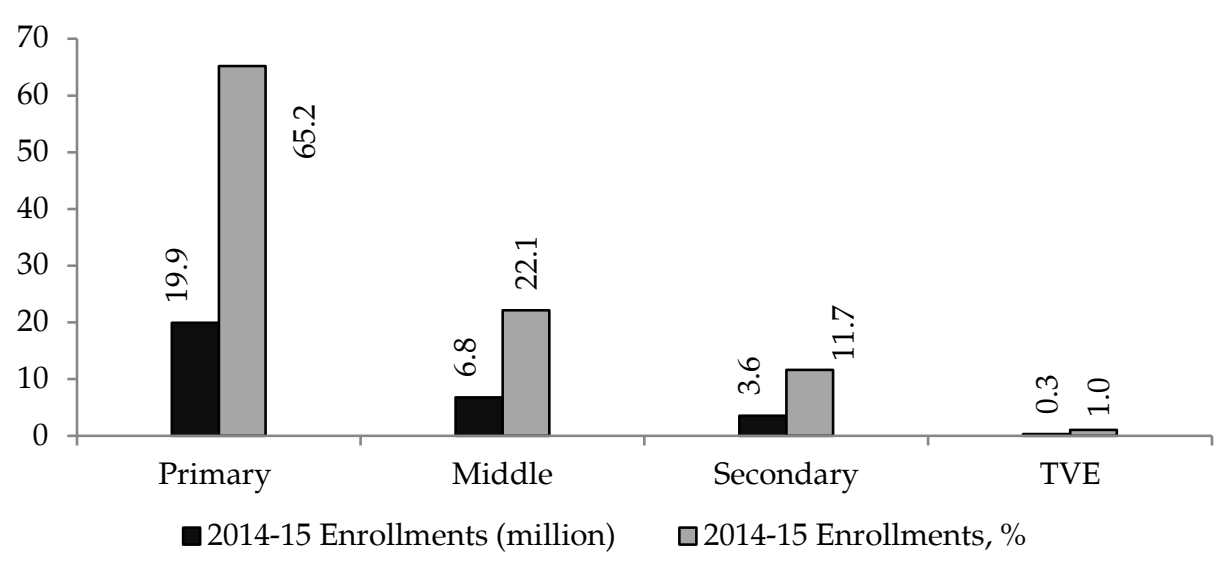

Source: Pakistan Bureau of Statistics (2016).

When it comes to the allocation of resources, education and skills are badly neglected. University enrolment is just over 1.8 million while only 0.3 million are enrolled in any formal technical education. This figure compares unfavorably with both developed and developing countries and affects productivity. Turkish enrolment in technical skills is around 35 percent of the relevant age cohort.

Machin and Van Reenen (2007) regard higher skills as an important factor in the production process, whereby higher-educated workers are more able to respond to new technologies such as ICT than less educated workers. They are also better able to react to organizational changes in modern firms such as the decentralization of decision making and control, collective work, job rotation and skills segregation and homogenization. This nonneutral technological change makes higher-skilled workers much more attractive to employers and rising worker skills could perhaps create their own demand.

An example of skewed priorities in Pakistan is the IslamabadRawalpindi metro bus infrastructure, which cost about Rs 45 billion over 15 months (nearly 11 times the annual school budget of Rawalpindi). The quality of teachers, education delivery and the books and subjects taught need a drastic overhaul. 


\subsection{Social and Economic Returns on Skills Development}

There is inadequate recognition of the economic and social returns of secondary, technical and vocational education in Pakistan. It has been estimated from OECD panel data that the productivity premium at the firm level for a trained worker is about 23 percent, with a wage premium of training of about 12 percent (Konings \& Vanormelingen, 2010). This supplements the international data, which points out that countries with a large proportion of students enrolled in upper secondary vocational programs have significantly higher rates of school attendance and completion at the higher upper secondary level. In the US, 90 percent of students attending a comprehensive high school take at least one occupation-specific course (Bishop \& Mane, 2005).

Ireland is an excellent example of a country that has changed its educational attainment and skills profile. In 1972, half the workforce had only primary education; by 2002, 63 percent had higher secondary and tertiary education. With a highly creative and talented workforce, an open economy and a competitive corporate tax environment, Ireland is now the second largest exporter of computer and IT services in the world, hosting eight of the ten leading companies with exports of over US\$55 billion in 2014.

The development of higher and different skills will affect the growth of new startups, but these will need to be regularly updated. This is where the state comes in. SMEs need venture capital and angel finding. However, funding for SMEs is less of a bottleneck than technology intelligence and help with change management. The policy framework required for SMEs in Pakistan would be to enhance technical skills and the organizational capacity of the client, provide training in financial and business models, provide 'change' intelligence and facilitate venture capital and angel funds, especially for new technology-based firms (NTBFs).

\section{The New Technology-Based Firm}

Becoming an entrepreneur involves changing the external environment from one state (that without the venture) to another (one with the venture). This causes a basic discontinuity in the competitive structure of the industry and can result in the creation of an altogether new industry. New technology enterprises and startups have different dynamics of evolving into mature businesses and involve activity, technology levels and business processes, and of course early death. The process must be viewed as a complete system, from the product concept to an acceptable finished 
product in the context of market share and the stage of the organization in the firm's lifecycle.

NTBFs are also quite vulnerable in the initial stages (the initiation, survival and growth phases) and face rapidly changing technology management activities and matters of sustainable supply chains, which include not just hardware and software, but also people with the right skills and their sudden exit to potential competitors and further new startups. The state can help by providing 'changing technology' intelligence.

It has been suggested that NTBFs are more likely to be initiated by employees working in small companies, which foster new startups because they are exposed to entrepreneurial working conditions and the learning opportunities are greater than in bigger firms (Werner \& Moog, 2009; Parker, 2009). Normally, NTBFs do not evolve in a linear fashion from stage to stage and certain stages can be bypassed when required in a rapidly changing situation (Savioz, Luggen \& Tschirky, 2003). This is also where the state comes in, as occurred in East Asia, Korea, China and Brazil, which have unorthodox policies to encourage such startups.

In the US, the impact of the Bayh-Dole Act on the entrepreneurship of scientists was measured by their propensity for starting a new firm. Audretsch et al. (2011) show that scientists who are on the board of a company or scientific advisory board and publish frequently with scientists employed in industry have a greater propensity for engaging in entrepreneurial activity.

\subsection{Change Agents}

Three types of agents can promote productivity and competition in a firm. First, there are the companies in the region (including their customers and suppliers) that represent the production component of the regional innovation system (Khan, 2016). Second, these need to be backed up by innovation support from universities, technical colleges, vocational training organizations and R\&D institutes as well as business associations and financial institutions. Finally, there is need for technology transfer agencies such as KISTEP in Korea. With these in place, it will be possible to develop a soft infrastructure and social capital. 


\subsection{Productivity and Frontier Firms}

At a general level, productivity drivers may be identified either at the level of the firm or across firms and countries. ${ }^{2}$ In the former, the firm culture, incentive structure and quality of human and physical capital will dominate. Across firms and countries, the spillovers from geographical proximity and even outside the region will be determined by regulation, trade and being part of supply chains. Product innovation in products and technology adoption are common drivers of productivity in all firms.

Firms operating at the frontiers of technology generally show higher productivity and productivity growth than larger, older firms (Figure 9) or those operating in nonfrontier areas (Andrews, Criscuolo \& Gal, 2015). They are younger, more flexible and more likely to file patents. The authors attribute this gap to a "highly uneven process of technological diffusion, which is consistent with a model whereby global frontier technologies only diffuse to laggards once they are adapted to country-specific circumstances by the most productive firms within each country." Further, a proper policy framework can promote productivity diffusion by sharpening firms' incentives to adopt technology and promoting a market environment.

Figure 9: Productivity lag between frontier firms and older firms
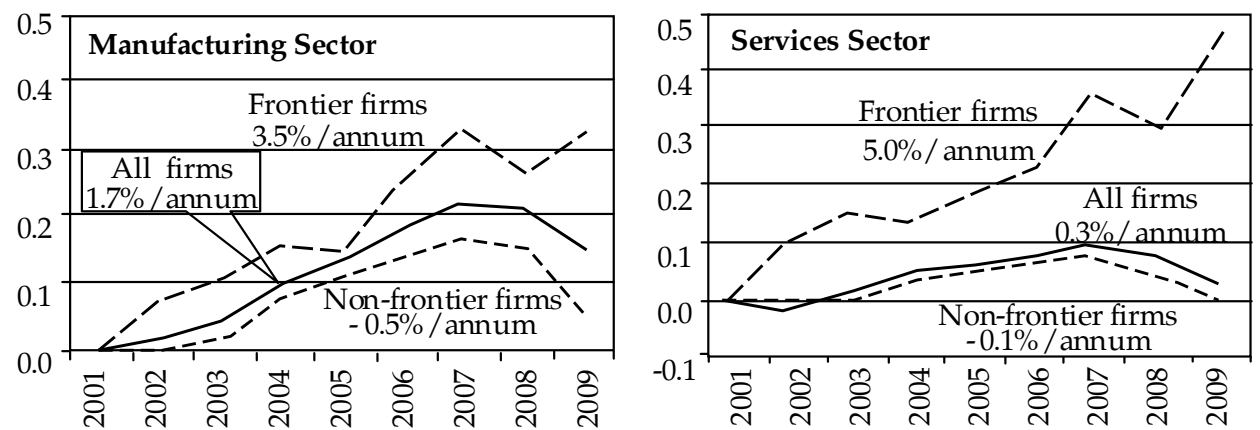

Source: Andrews et al. (2015).

This would require reallocating resources to the most productive firms in addition to $R \& D$ tax incentives, industry-university $R \& D$ collaboration and patent protection. Greater industry-academia R\&D collaboration would facilitate technology diffusion to smaller and less productive firms by providing new avenues of knowledge such as advanced

2 See: http://www.kauffman.org/microsites/state-of-the-field/topics/firm-and-industry-dynamics/ productivity-growth 
machinery and instruments and skilled scientists. Trading with frontier firms and participation in global value chains, coupled with better egovernance and major reallocations for skills enhancement, are key drivers of productivity and innovation gains.

\subsection{Policies, Foresight and Internal Transfer of Technology}

The efficacy and impact of state policies or advice to policymakers will depend on three factors: relevance, stakeholder interests and the jurisdiction of those who will fund, implement and monitor these programs. It will also depend on the nature of the work that must follow, which is distinct from making buildings. An important role for the government will be to provide foresight and map trends: this could help pick potential winners, enable better matchmaking with stakeholders, redraw existing and future allocations and develop better skills and standards.

Conducting regular foresight exercises is now common in many countries. While the impact of such exercises is still being examined, they do have a significant effect on designing and shaping national innovation policies and the necessary innovation systems and structures, including change management. Mu and Ren (2009) study this impact on the scientific community, on making S\&T policy decisions and on the public understanding of S\&T in China, while Yi, Kim and Yu (2016) conduct a similar study for Korea. Both give insight into coherent policymaking and implementation through foresight exercises.

Currently, a major revolution is underway in the energy sector: efficiency in the generation and use of electricity and the grid integration of renewable energy are major drivers of the new energy scenario. This sector needs urgent attention, as the window of opportunity is small, with many new players appearing on the scene.

Pakistan has developed major technological capabilities in its national government laboratories, especially those in the strategic sector. These cover modules for power plants, computers and controls, agriculture and water management, seed development, biotechnology and medicine. It is time to transfer these to local industry. Such an internal technology transfer could be extremely beneficial, especially for small businesses. The latter are more efficient innovators and state assistance would reduce the cost of negotiating technology agreements. 
The allocation of resources for basic scientific research has always been controversial because its economic payoffs are uncertain and likely to be delayed, whereas technology is expected to generate 'rents' or profits much sooner. For a country such as Pakistan, another issue is the protection and enforcement of intellectual property rights and patents, which is crucial in the modern part of the economy based on medium-tech and high-tech enterprises.

\section{Conclusion}

With the China-Pakistan Economic Corridor in the news, generating employment and matching skills with demand in the changing workplace will be central to success in poverty reduction, economic growth and social mobility. The national education and training system is, unfortunately, not in sync with these objectives and is due for a major overhaul.

Low literacy in Pakistan is a natural outcome of the system's lack of responsiveness to the economic needs of students and explains to a great extent the high dropout rate after five years of schooling. Recent studies suggest that extreme convictions on either side of the public-private divide are no longer supported and an intermediate position exists between pure market forces and rigid state planning. This "rare historic opportunity for planning industrial policies" (Rodrik, 2004) allows the state to be responsible for basic strategic and coordinating roles in the productive sectors, irrespective of the intensity of globalization.

Education and training are the most successful policy instruments for state intervention. This has happened in every newly industrialized country of the last few decades and is also actively pursued by the OECD countries. Education with skills is now viewed as a right for young people and a core responsibility of the state. My extensive interaction with industry and business suggests that the private sector in Pakistan is willing and able to participate with the public sector if its stake is duly recognized. This is in line with Maclean (2005), who argues that, "in many countries, secondary education has become the weakest link in the education chain." It is now receiving more attention and policy priority because it is seen not just as a bridge between primary and tertiary education, but also as an active instrument for preparing young people to enter the workforce of a fastchanging global economy.

General education will not be displaced. It will be supplemented to the extent of, say, 15-20 percent with economically relevant courses related 
to the productive sectors of the economy (services, industry and agriculture). This needs to be augmented with 'soft' skills such as communications, interpersonal skills and team-based approaches. For both streams, teachers are the long pole that holds up the reformed structure. All programs must therefore be built around well-trained and well-paid teachers. At the institutional level, the capacity for data collection and analysis of the labor market needs to be strengthened while maintaining a balance between institutional autonomy and the public accountability of financing instruments and the monitoring of outcomes.

It is argued that internal technology transfer can and should be facilitated between the best in the country and not-as-good technical institutions. This could take the form of 'mother institutions' where the national laboratories in particular could help to steer quality matters and benchmarking. These could include major institutions and industries in sectors such as power, chemicals and pharmaceuticals, IT, agribusiness, mining and the relevant departments in academia. 


\section{References}

Abramovitz, M. (1994). The origins of the post-war catch-up and convergence boom. In J. Fagerberg, B. Verspagen \& G. von Tunzelmann (Eds.), The dynamics of technology, trade and growth. Aldershot: Edward Elgar.

Andrews, D., Criscuolo, C., \& Gal, P. (2015). Frontier firms, technology diffusion and public policy: Micro-evidence from OECD countries. Paris: OECD.

Audretsch, D. B., Falck, O., Heblich, S., \& Lederer, A. (Eds.). (2011). Handbook of research on innovation and entrepreneurship. Cheltenham: Edward Elgar.

Bailetti, T. (2012). Technology entrepreneurship: Overview, definition and distinctive aspects. Technology Innovation Management Review, 2(2), 5-12.

Barro, R. J., \& Lee, J.-W. (2000). International data on educational attainment updates and implications (Working Paper No. 7911). Cambridge, MA: National Bureau of Economic Research.

Berteletti, E., Morel, T., \& Teulieres, M. (2016). R\&D readiness. McKinsey Quarterly, 3, 18-20.

Bishop, J. H., \& Mañe, F. (2005). Economic returns to vocational courses in US high schools. In J. Lauglo \& R. Maclean (Eds.), Vocalization of secondary education revisited (pp. 329-362). Rotterdam: Springer.

Dasgupta, P., \& David, P. A. (1994). Toward a new economics of science. Research Policy, 23(5), 487-521.

Gerschenkron, A. (1962). Economic backwardness in historical perspective. Cambridge, MA: Belknap Press.

Khan, S. H. (2016, August). Value creation in the innovation economy. Paper presented at the $2^{\text {nd }}$ Asian Innovation Forum, Seoul, Korea.

Konings, J., \& Vanormelingen, S. (2010). The impact of training on productivity and wages: Firm-level evidence (Discussion Paper No. 4731). Bonn: Institute for the Study of Labor. 
Lundvall, B. A. (1992). National systems of innovation: Towards a theory of innovation and interactive learning. London: Pinter Publishers.

Lundvall, B. A. (2005, June). National innovation systems - analytical concept and development tool. Paper presented at the DRUID 10 th Anniversary Summer Conference, Copenhagen.

Machin, S., \& Van Reenen, J. (2007). Changes in wage inequality (Special Paper No. 18). London: Center for Economic Performance.

Maclean, R. (2005). Setting the context: An overview of secondary education reform with particular reference to the Asia-Pacific region. In J. Lauglo \& R. Maclean (Eds.), Vocalization of secondary education revisited. Rotterdam: Springer.

Manyika, J., Chui, M., Bughin, J., ... Marrs, A. (2013). Disruptive technologies: Advances that will transform life, business and the global economy. Washington, DC: McKinsey Global Institute.

Morishima, M. (1982). Why has Japan succeeded? Western technology and the Japanese ethos. New York: Cambridge University Press.

Mu, R., \& Ren, Z. (2009). Technology foresight towards 2020 in China: The practice and its impacts. Unpublished manuscript, Institute of Policy and Management, Chinese Academy of Sciences, Beijing.

OECD. (2015). The future of productivity. Paris: Author.

Parker, S. C. (2009). Why do small firms produce the entrepreneurs? Journal of Socio-Economics, 38(3), 484-494.

Polanyi, M. (1962). The republic of science: Its political and economic theory. Minerva, 1(1), 54-73.

Rodrik, D. (2004). Industrial policy for the twenty-first century. Cambridge, MA: Harvard University Press.

Rodrik, D. (2013). Premature deindustrialization. Unpublished manuscript, Harvard University, Cambridge, MA.

Romer, P. M. (1994). The origins of endogenous growth. Journal of Economic Perspectives, 8, 3-22. 
Savioz, P., Luggen, M., \& Tschirky, H. (2003, July-August). Technology intelligence: Structuring it into the new technology-based firm. Tech Monitor, 41-46.

Schumpeter, J. A. (1976). Capitalism, socialism and democracy. New York: Harper and Row.

Werner, A., \& Moog, P. (2009). Why do employees leave their jobs for selfemployment? The impact of entrepreneurial working conditions in small firms. Retrieved from https:/ /mpra.ub.uni-muenchen.de/18826/

World Bank. (2015). Global economic prospects: Having fiscal space and using it. Washington, DC: Author.

World Economic Forum. (2016). The global competitiveness report 2015-2016. Geneva: Author.

World Intellectual Property Organization. (2015). WIPO IP facts and figures. Geneva: Author.

Yi, S.-K., Kim, S.-I., \& Yu, J. W. (2016). KISTEP 10 emerging technologies in 2016. Seoul: Korea Institute of S\&T Evaluation and Planning. 